\title{
Effects of tree species, stand age and land-use change on soil carbon and nitrogen stock rates in northwestern Turkey
}

Temel Sariyildiz, Gamze Savaci, Inci Sevinç Kravkaz

\begin{abstract}
Effects of tree species, stand age and land-use change on soil carbon and nitrogen stock rates were investigated in the northwest of Turkey using 4 common tree species as black pine (Pinus nigra Arnold.), Scots pine (Pinus sylvestris L.), Oriental beech (Fagus orientalis Lipsky) and Uludag fir (Abies nordmanniana ssp. bornmuelleriana). Three tree species (black pine, Scots pine and Oriental beech) were used to investigate the differences in soil $\mathrm{C}$ and $\mathrm{N}$ among tree species. Old and young Uludag fir stands and adjacent grassland were used to study the differences in soil $\mathrm{C}$ and $\mathrm{N}$ with stand age and land-use change. Mineral soil samples were taken from $0-10 \mathrm{~cm}$ and $10-20 \mathrm{~cm}$ soil depths, and analyzed for $\mathrm{pH}$, soil texture, bulk density, total soil carbon and total nitrogen. The total soil carbon and total nitrogen pools were then calculated by multiplying soil volume, soil bulk density, and the total soil carbon or total nitrogen content. Results showed significant differences in soil carbon and nitrogen contents, carbon/nitrogen ratios and stock rates among the three species, and between old and young fir stands and grassland. In general, when $0-20 \mathrm{~cm}$ soil depth was considered, mean soil carbon stock rate was the highest under black pine $\left(79 \mathrm{Mg} \mathrm{C} \mathrm{ha}^{-1}\right)$ followed by Scots pine $\left(73 \mathrm{Mg} \mathrm{C} \mathrm{ha}^{-1}\right)$ and beech (67 Mg C ha-1), whereas mean soil nitrogen stock rate was the highest under beech $\left(9.57 \mathrm{Mg} \mathrm{N} \mathrm{ha}^{-1}\right)$ followed by Scots pine $\left(5.77 \mathrm{Mg} \mathrm{N} \mathrm{ha}^{-1}\right)$ and black pine $\left(4.20 \mathrm{Mg} \mathrm{N} \mathrm{ha}^{-1}\right)$. Young fir stands showed lower soil carbon stock, but higher soil nitrogen stock rates compared to old fir stands and grassland. Our results demonstrated that tree species, stand tree age and land-use change can have significant effects on soil carbon and nitrogen content and stocks rates. These findings can help to enhance forest management activities, such as selection of tree species for carbon sequestration in plantation systems, design of sustainable agroforestry systems, and improvement of biogeochemical models.
\end{abstract}

Keywords: Forest Soil, Climate Change, Soil Carbon and Nitrogen Budget, Grassland, Turkey

It has been estimated that approximately $123 \mathrm{Pg}$ of carbon (C) were released to the atmosphere between 1850 and 1990 due to land-use change (Houghton 1999). Nitrogen $(\mathrm{N})$ deposition has also increased more than tenfold since the last 150 years due to the intensification of human activities such as production and application of nitrogenous fertilizer, and fossil fuel combustion (Hobbie 2008), and the $\mathrm{N}$ deposition rate is predicted to be enhanced in the next few decades (Galloway et al. 2004). The increa-

Kastamonu University, Faculty of Forestry, Division of Soil Science and Ecology, 37100 Kastamonu (Turkey)

@ Temel Sariyildiz (t_sariyildiz@yahoo.com)

Received: Jan 17, 2015 - Accepted: Feb 26, 2015

Citation: Sariyildiz T, Savaci G, Kravkaz IS (2015). Effects of tree species, stand age and landuse change on soil carbon and nitrogen stock rates in northwestern Turkey. iForest 9: 165170. - doi: 10.3832/ifor1567-008 [online 2015-06-18]

sing $\mathrm{N}$ availability would impact $\mathrm{C}$ and $\mathrm{N}$ cycling in terrestrial ecosystems (Jiang et al. 2010). Changes in soil carbon and nitrogen after conversion of forests to pasture and grassland vary greatly among sites. Differences in carbon and nitrogen storage between pasture, grassland and forest sites are attributed to variations in vegetation type, tree stand age and physical properties of soils (Osher et al. 2003).

Forests contain 20 to 100 times more biomass $C$ per unit area than agricultural lands, therefore the conversion of forest to grassland or cropland generally reduces the amount of carbon on land (Houghton 1992). Approximately half of Earth's terrestrial $C$ is in forests $\left(1146 \times 10^{15} \mathrm{~g}\right)$, and about two-thirds of such amount is retained in soil pools (Goodale et al. 2002). A number of studies have shown that tree species can differ in their influence on the stock and composition of soil carbon (SC - Vesterdal et al. 2008). Inputs and chemistry of organic detritus $C$ from different tree species can affect SC (Eviner \& Chapin 2003). Tree species could potentially cause a "bridging" effect between SC and clay par- 


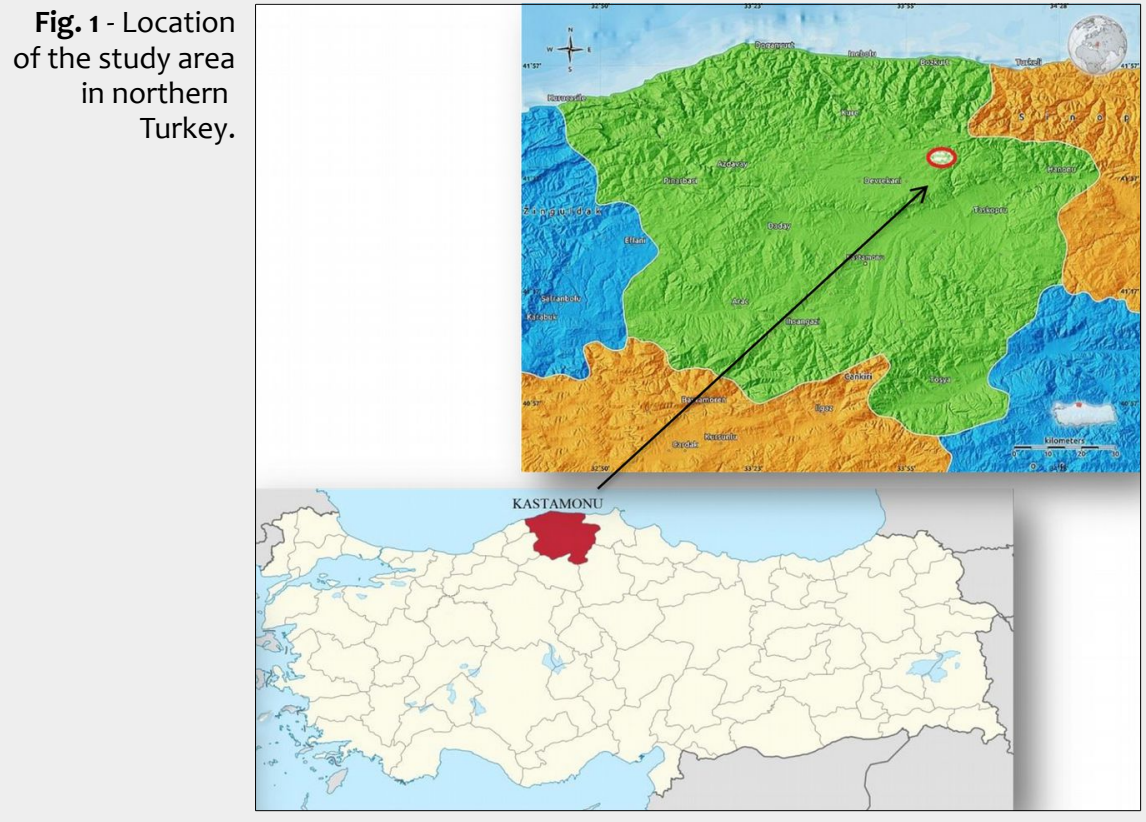

ticles via their influence on cation chemistry, thereby reducing $\mathrm{C}$ decomposition (Mulder et al. 2001). In addition, low soil pH resulted from the inputs of acidic tissues of various tree species may enhance SC accumulation through microbial inhibition (Beets et al. 2002). In other studies, nitrogen pools and $\mathrm{C} / \mathrm{N}$ ratios have been suggested as indicators of $C$ sequestration potential in soils (De Vries et al. 2006). The variability in soil $\mathrm{C} / \mathrm{N}$ ratios and $\mathrm{N}$ retention can be closely linked with variation in tree species composition (Lovett et al. 2002). Several studies have reported the influence of tree species on microbial processes related to $\mathrm{C}$ and $\mathrm{N}$ cycling (Menyailo et al. 2002).

Recent studies on the role of soil carbon pools for mitigation of greenhouse gases have highlighted the need for more knowledge on tree species effects (Jandl et al. 2007). Forest management, including a change in tree species and stand age has been accepted as a measure for mitigation of atmospheric $\mathrm{CO}_{2}$ in national greenhouse gas budgets. However, quantitative estimates of tree species effect on soil $\mathrm{C}$ and $\mathrm{N}$ pools are still scarce and not much study are available in the literature for Turkey. The knowledge of soil $\mathrm{C}$ and $\mathrm{N}$ pools under common Turkish tree species is even more scarce and inconclusive, whereas studies in Europe indicated strong differences in soil
$\mathrm{C}$ and $\mathrm{N}$ between ash, lime, beech, maple, oak, Norway spruce species (Vesterdal et al. 2008).

In this paper, we set up a study in the northeast of Turkey to explore the differences in soil $C$ and $N$ : (1) between tree species using black pine (Pinus nigra Arnold.), Scots pine (Pinus sylvestris L.) and Oriental beech (Fagus orientalis Lipsky); (2) with stand age using old and young stands of Uludag fir (Abies nordmanniana ssp. bornmuelleriana); and (3) with land use change using grassland and adjacent young and old Uludag fir stands. Differences in mineral soil $\mathrm{C}$ and $\mathrm{N}$ content and stock capacity were studied at two soil depths of $0-10 \mathrm{~cm}$ and $10-20 \mathrm{~cm}$.

\section{Materials and methods}

\section{Site description and sampling}

The study was carried out in Kastamonu, northwest of Turkey ( $41^{\circ} 23^{\prime} 19^{\prime \prime} \mathrm{N}, 33^{\circ} 46^{\prime}$ $57^{\prime \prime} \mathrm{E}$ - Fig. 1). The altitudes of the studied areas were between 800 and $1200 \mathrm{~m}$ a.s.l. (Tab. 1). The aspect of the studied site was Northwest (NW). In the study area, winters are long, cold and snowy, whereas summers are short and warm. The seasonal and daily temperatures show large extreme values and precipitation is generally low. Weather data for the period 1975-2010 (Kastamonu Meteorology Station, 800 m a.s.l.) indicate that precipitation averages $490 \mathrm{~mm}$ annually. Average monthly temperatures range from $20.2^{\circ} \mathrm{C}$ in July to -0.8 ${ }^{\circ} \mathrm{C}$ in January. Parent material of the studied area was mainly a granite/quartz mixture. Geomorphology and tree species distribution at the study site is shown in Fig. 2 .

The study area consists of broadleaf and conifer stands with age between 40 and 150 years. Stands with age of approximately 70-90 years, homogenous soils, similar slope position (NW) and located in the center of the forest were selected, and soil samples collected at two different sites: at the first site, stands with black pine (Pinus nigra Arnold.), beech (Fagus orientalis Lipsky) and Scots pine (Pinus sylvestris L.) stands were selected at the elevation of 1000,1100 and $1200 \mathrm{~m}$ a.s.l., respectively. At the second site, old and young Uludag fir (Abies nordmanniana ssp. bornmuelleriana) stands (82 and 45 year-old, respectively) and adjacent grassland situated at $800 \mathrm{~m}$ a.s.l. were chosen.

Soil sampling was conducted in the autumn 2012 and spring 2013. Three adjacent subplots (replicates $-20 \times 20 \mathrm{~m}$ ) were identified and sampled for each stand type. Humus form of the stands was moder like. From the forest floor, all horizons (L, F and $\mathrm{H})$ that could be distinguished separately with sufficient thickness were individually measured. Mineral soil sampling was restricted to the upper $20 \mathrm{~cm}$, where changes in soil $\mathrm{C}$ and $\mathrm{N}$ are expected to occur. A soil core device with an inner diameter of $5 \mathrm{~cm}$ was used for soil sampling to a depth of 20 $\mathrm{cm}$. Mineral soil sample cores were taken from $0-10 \mathrm{~cm}$ and $10-20 \mathrm{~cm}$ soil depth, and passed through a $2 \mathrm{~mm}$ sieve to remove stones and gravel.

\section{Soil analysis}

Soil $\mathrm{pH}$ was measured for samples from the $0-20 \mathrm{~cm}$ layer using a 1:2.5 mixture of deionized water and soil using a glass calomel electrode (Orion 420 digital $\mathrm{pH}$ meter, Fisher, Pittsburg, PA, USA) after equilibration for $1 \mathrm{~h}$. Moisture content of samples was calculated by weight loss after oven-drying aliquots of ca. $10 \mathrm{~g}$ of soil for $24 \mathrm{~h}$ at $105{ }^{\circ} \mathrm{C}$. Soil texture (sand, silt and clay) was determined on soil samples from the $0-20 \mathrm{~cm}$ layer using the hydrometer method of Bouyoucos (1935) in a soil suspension of $50 \mathrm{~g}$ of soil in $1 \mathrm{~L}$ of $\mathrm{H}_{2} \mathrm{O}$ (Gülçur 1974, modified from Bouyoucos 1962). Samples were pretreated with am-

Tab. 1 - Mean elevation, stand age, annual temperature (MAT) and annual precipitation (MAP), soil texture, soil pH and forest floor horizon thickness $(\mathrm{cm})$ of the study stands. Different letters indicate significant differences between tree species $(P<0.05, n=9)$.

\begin{tabular}{|c|c|c|c|c|c|c|c|c|c|c|c|}
\hline \multirow{2}{*}{ Species/Stand } & \multirow{2}{*}{$\begin{array}{l}\text { Elevation } \\
\text { (m.a.s.l) }\end{array}$} & \multirow{2}{*}{$\begin{array}{c}\text { Stand age } \\
(y r)\end{array}$} & \multirow{2}{*}{$\begin{array}{l}\text { MAT } \\
\left({ }^{\circ} \mathrm{C}\right)\end{array}$} & \multirow{2}{*}{$\begin{array}{l}\text { MAP } \\
(\mathrm{mm})\end{array}$} & \multicolumn{3}{|c|}{ Texture sand silt clay } & \multirow{2}{*}{$\mathrm{pH}$} & \multirow{2}{*}{$\begin{array}{l}\text { Litter } \\
(\mathrm{cm})\end{array}$} & \multirow{2}{*}{$\begin{array}{l}\text { Fragmen- } \\
\text { ted }(\mathrm{cm})\end{array}$} & \multirow{2}{*}{$\begin{array}{c}\text { Humus } \\
\text { (cm) }\end{array}$} \\
\hline & & & & & Sand (\%) & Silt (\%) & Clay (\%) & & & & \\
\hline Black pine & 1000 & 85 & 9.5 & 490 & 61 & 19 & 20 & 5.4 & $1.59^{b}$ & $3.35^{b}$ & $1.21^{\mathrm{b}}$ \\
\hline Oriental Beech & 1100 & 77 & 9.0 & 490 & 59 & 23 & 18 & 5.7 & $1.80^{c}$ & $3.75^{c}$ & $2.89^{c}$ \\
\hline Scots pine & 1200 & 75 & 8.5 & 490 & 63 & 21 & 16 & 5.5 & $1.48^{\mathrm{b}}$ & $3.12^{b}$ & $1.15^{\mathrm{b}}$ \\
\hline Fir & 800 & 82 & 11.5 & 550 & 66 & 19 & 15 & 5.9 & $1.27^{\mathrm{a}}$ & $2.90^{\mathrm{a}}$ & $0.80^{\mathrm{a}}$ \\
\hline Young fir & 800 & 45 & 11.5 & 550 & 64 & 19 & 17 & 6.0 & $1.13^{\mathrm{a}}$ & $2.56^{\mathrm{a}}$ & $0.75^{\mathrm{a}}$ \\
\hline Grassland & 800 & - & 11.5 & 550 & 67 & 17 & 16 & 6.1 & $\mathrm{n} / \mathrm{a}$ & $\mathrm{n} / \mathrm{a}$ & $\mathrm{n} / \mathrm{a}$ \\
\hline
\end{tabular}


monium hydroxide $\left(\mathrm{NH}_{4} \mathrm{OH}\right)$ to remove organic matter and NaHMP was used as a dispersal agent to minimize foaming. Bulk density was determined by weight loss after drying the undisturbed soil cores. Soil carbon content was quantified with using a Leco dry combustion element analyzer. Total $\mathrm{N}$ was determined by Kjeldal digestion (Allen 1989) followed by analysis of ammonium by the indophenols method using an auto-analyzer device for 2 days at $105^{\circ} \mathrm{C}$. The SC or nitrogen pool were calculated by multiplying soil volume, soil bulk density, and SC or nitrogen content and expressed as $\mathrm{Mg} \mathrm{ha}^{-1}$ (Lee et al. 2009). Soil mass was calculated as follows (eqn. 1 ):

$$
M_{i}=B D_{i} \cdot T_{i} \cdot 10^{4}
$$

where $M_{\mathrm{i}}$ is dry soil mass $\left(\mathrm{Mg} \mathrm{ha}^{-1}\right), B D_{\mathrm{i}}$ is bulk density $\left(\mathrm{Mg} \mathrm{m}^{-3}\right), T_{\mathrm{i}}$ is the thickness of the $i$-th soil layer $(\mathrm{m})$, and $10^{4}$ is the unit conversion factor $\left(\mathrm{m}^{2} \mathrm{ha}^{-1}\right)$. The fixed depth (FD) determination of areal $\mathrm{C}$ or $(\mathrm{N})$ stock is calculated as follows (eqn. 2):

$$
C_{i-\text { fixed }} \vee N_{i-\text { fixed }}=\left(\left[C_{i}\right] \vee\left[N_{i}\right]\right) \cdot M_{i}
$$

where $C_{\text {iffixed }}$ is the C (or $N_{\text {iffixed }}$ is the $\mathrm{N}$ ) mass to a fixed depth ( $\mathrm{kg} \mathrm{C}$ or $\mathrm{N} \mathrm{ha}{ }^{-1}$ ) and $\left[C_{\mathrm{i}}\right]$ or $\left[N_{\mathrm{i}}\right]$ is the $\mathrm{C}$ or $\mathrm{N}$ concentration $(\mathrm{kg} \mathrm{C}$ or $\mathrm{N} \mathrm{Mg}^{-1}$ ).

\section{Data analysis}

Analysis of variance (ANOVA) was applied to test for differences in soil carbon and nitrogen concentrations and stocks among stands of the three tree species (black pine, Scots pine and beech), and among the old fir stand, the young fir stand and the grassland using the SPSS ${ }^{\oplus}$ software $v$. 11 for Windows ${ }^{\circledast}$ (IBM, Armonk, NY, USA). Tukey's honestly significant difference (HSD) test $(\alpha=0.05)$ was applied to test for differences among mean values.

\section{Results}

Forest floor structure differed between tree stands (Tab. 1). In general, beech stands had the thickest forest floor $(L=1.80$ $\mathrm{cm}, \mathrm{F}=3.75 \mathrm{~cm}, \mathrm{H}=2.89 \mathrm{~cm}$ ), whereas young fir stands showed the thinnest forest floor $(L=1.13 \mathrm{~cm}, \mathrm{~F}=2.56 \mathrm{~cm}, \mathrm{H}=0.75 \mathrm{~cm}$ ). Soil texture and $\mathrm{pH}$ values did not vary significantly between tree species ( $P>0.05$ - Tab. 1).

\section{Differences in soil C and N stocks between tree species}

Mean soil bulk density and carbon and nitrogen concentrations in three species analyzed are given in Tab. 2. Soil bulk density increased with increase in soil depth. Soil bulk density was generally lower under the black pine stand than under beech and Scots pine stands.

Black pine stand had the greatest SC concentration in the top $10 \mathrm{~cm}(4.13 \%)$, followed by Scots pine $(3.67 \%)$ and beech (3.18\%). Soil carbon concentration decreased with increasing soil depth. At the 10-20

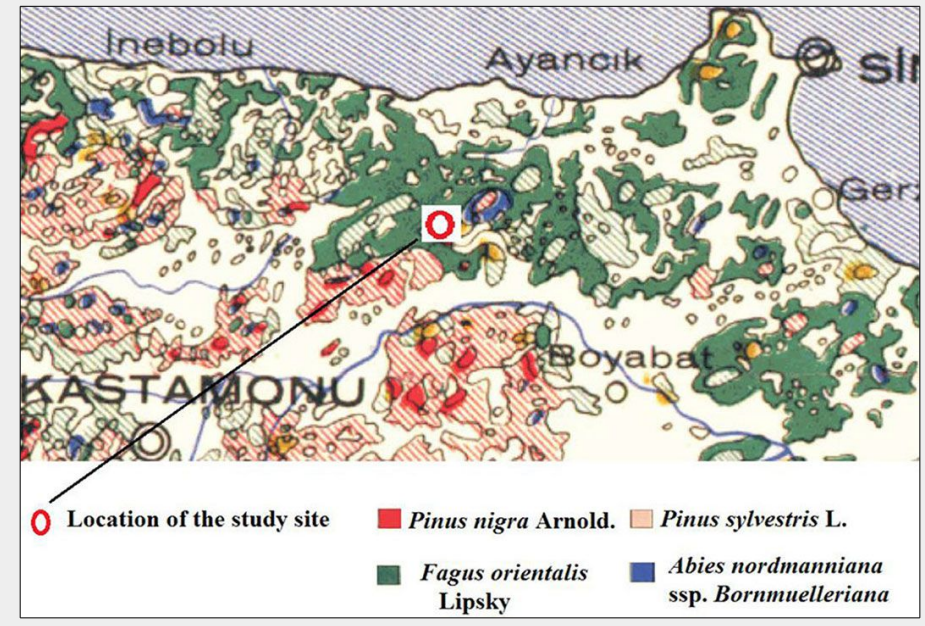

Fig. 2 - Geomorphology and tree species distribution at the study site.

$\mathrm{cm}$ depth, black pine stand still had the greatest SC concentration (2.33\%), whereas beech stand had the lowest SC concentration (1.85\%). In general, when samples from the $0-20 \mathrm{~cm}$ soil depth were considered, SC concentration was highest under black pine $(3.23 \%)$ and lowest in beech soil (2.51\%). Compared to SC concentration, total nitrogen concentration at the top 10 $\mathrm{cm}$ was lowest under black pine $(0.20 \%)$ and highest under beech (0.44\%). Total nitrogen concentration also decreased with increasing soil depth. At the $10-20 \mathrm{~cm}$ depth, black pine stand still had the lowest $(0.11 \%)$ and beech stand had the highest total nitrogen concentration (0.33\%). At the $0-20 \mathrm{~cm}$, total nitrogen concentration was lowest under the black pine stand

Tab. 2 - Mean soil bulk density $\left(\mathrm{Mg} \mathrm{m}^{-3}\right)$, soil carbon and nitrogen content (\%) in mineral topsoil per tree species. Different letters indicate significant differences between tree species $(P<0.05, n=9)$.

\begin{tabular}{lcccc}
\hline Species/Stand & $\begin{array}{c}\text { Depth } \\
(\mathbf{c m})\end{array}$ & Bulk density & Soil Carbon & Total Nitrogen \\
\hline Black pine & $0-10$ & $1.18^{\mathrm{a}}$ & $4.13^{\mathrm{c}}$ & $0.20^{\mathrm{a}}$ \\
& $10-20$ & $1.31^{\mathrm{a}}$ & $2.33^{\mathrm{c}}$ & $0.11^{\mathrm{a}}$ \\
& $0-20$ & $1.24^{\mathrm{a}}$ & $3.23^{\mathrm{c}}$ & $0.15^{\mathrm{a}}$ \\
Scots pine & $0-10$ & $1.21^{\mathrm{a}}$ & $3.67^{\mathrm{b}}$ & $0.25^{\mathrm{b}}$ \\
& $10-20$ & $1.42^{\mathrm{b}}$ & $2.01^{\mathrm{b}}$ & $0.20^{\mathrm{b}}$ \\
& $0-20$ & $1.31^{\mathrm{b}}$ & $2.84^{\mathrm{b}}$ & $0.22^{\mathrm{b}}$ \\
Oriental beech & $0-10$ & $1.29^{\mathrm{b}}$ & $3.18^{\mathrm{a}}$ & $0.44^{\mathrm{c}}$ \\
& $10-20$ & $1.45^{\mathrm{b}}$ & $1.85^{\mathrm{a}}$ & $0.33^{\mathrm{c}}$ \\
& $0-20$ & $1.35^{\mathrm{b}}$ & $2.51^{\mathrm{a}}$ & $0.39^{\mathrm{c}}$ \\
\hline
\end{tabular}

Tab. 3 - Mean carbon and nitrogen stocks $\left(\mathrm{Mg} \mathrm{ha}^{-1}\right)$ and $\mathrm{C} / \mathrm{N}$ ratios in mineral topsoil per tree species. Different letters indicate significant differences between tree species $(P<0.05, n=9)$.

\begin{tabular}{lcccc}
\hline Species/Stand & $\begin{array}{c}\text { Depth } \\
(\mathbf{c m})\end{array}$ & $\begin{array}{c}\text { Carbon } \\
(\mathbf{C})\end{array}$ & $\begin{array}{c}\text { Nitrogen } \\
(\mathbf{N})\end{array}$ & C/N \\
\hline Black pine & $0-10$ & $48.3^{\mathrm{c}}$ & $2.37^{\mathrm{a}}$ & $21: 1$ \\
& $10-20$ & $30.6^{\mathrm{b}}$ & $1.83^{\mathrm{a}}$ & $17: 1$ \\
& $0-20$ & $78.8^{\mathrm{c}}$ & $4.20^{\mathrm{a}}$ & $19: 1$ \\
\hline Scots pine & $0-10$ & $44.5^{\mathrm{b}}$ & $2.98^{\mathrm{b}}$ & $15: 1$ \\
& $10-20$ & $28.5^{\mathrm{b}}$ & $2.79^{\mathrm{b}}$ & $10: 1$ \\
& $0-20$ & $72.9^{\mathrm{b}}$ & $5.77^{\mathrm{b}}$ & $13: 1$ \\
\hline Oriental beech & $0-10$ & $41.1^{\mathrm{a}}$ & $5.19^{\mathrm{c}}$ & $8: 1$ \\
& $10-20$ & $25.9^{\mathrm{a}}$ & $4.38^{\mathrm{c}}$ & $6: 1$ \\
& $0-20$ & $67.0^{\mathrm{a}}$ & $9.57^{\mathrm{c}}$ & $7: 1$ \\
\hline
\end{tabular}


Tab. 4 - Mean soil bulk density $\left(\mathrm{Mg} \mathrm{m}^{-3}\right)$, soil carbon and nitrogen content (\%) in mineral topsoil of young and old fir and grassland. Different letters indicate significant differences between tree species $(P<0.05, n=9)$.

\begin{tabular}{lrccc}
\hline Species/Stand & $\begin{array}{c}\text { Depth } \\
(\mathbf{c m})\end{array}$ & Bulk density & Soil Carbon & Total Nitrogen \\
\hline Fir & $0-10$ & $1.28^{\mathrm{a}}$ & $3.54^{\mathrm{c}}$ & $0.27^{\mathrm{b}}$ \\
& $10-20$ & $1.45^{\mathrm{a}}$ & $2.06^{\mathrm{b}}$ & $0.19^{\mathrm{b}}$ \\
Young Fir & $0-20$ & $1.29^{\mathrm{a}}$ & $2.80^{\mathrm{c}}$ & $0.23^{\mathrm{b}}$ \\
& $0-10$ & $1.22^{\mathrm{a}}$ & $3.14^{\mathrm{b}}$ & $0.31^{\mathrm{c}}$ \\
& $10-20$ & $1.34^{\mathrm{a}}$ & $1.71^{\mathrm{a}}$ & $0.22^{\mathrm{c}}$ \\
Grassland & $0-20$ & $1.23^{\mathrm{a}}$ & $2.42^{\mathrm{b}}$ & $0.27^{\mathrm{c}}$ \\
& $0-10$ & $1.45^{\mathrm{b}}$ & $2.33^{\mathrm{a}}$ & $0.22^{\mathrm{a}}$ \\
& $10-20$ & $1.73^{\mathrm{b}}$ & $1.79^{\mathrm{a}}$ & $0.13^{\mathrm{a}}$ \\
& $0-20$ & $1.59^{\mathrm{b}}$ & $2.06^{\mathrm{a}}$ & $0.17^{\mathrm{a}}$ \\
\hline
\end{tabular}

Tab. 5 - Mean carbon and nitrogen stocks $\left(\mathrm{Mg}\right.$ ha $\left.^{-1}\right)$ and $\mathrm{C} / \mathrm{N}$ ratios in mineral topsoil of young and old fir and grassland. Different letters indicate significant differences between tree species $(P<0.05, n=9)$.

\begin{tabular}{lrccr}
\hline Species/Stand & $\begin{array}{c}\text { Depth } \\
(\mathbf{c m})\end{array}$ & Carbon (C) & Nitrogen (N) & C/N \\
\hline Fir & $0-10$ & $43.0^{\mathrm{c}}$ & $3.32^{\mathrm{a}}$ & $13: 1$ \\
& $10-20$ & $27.9^{\mathrm{b}}$ & $2.60^{\mathrm{a}}$ & $11: 1$ \\
& $0-20$ & $70.9^{\mathrm{c}}$ & $5.93^{\mathrm{a}}$ & $12: 1$ \\
Young Fir & $0-10$ & $38.1^{\mathrm{b}}$ & $3.80^{\mathrm{b}}$ & $9: 1$ \\
& $10-20$ & $23.2^{\mathrm{a}}$ & $3.02^{\mathrm{b}}$ & $10: 1$ \\
& $0-20$ & $61.3^{\mathrm{a}}$ & $6.82^{\mathrm{b}}$ & $10: 1$ \\
\hline Grassland & $0-10$ & $33.7^{\mathrm{a}}$ & $3.26^{\mathrm{a}}$ & $12: 1$ \\
& $10-20$ & $30.9^{\mathrm{c}}$ & $2.55^{\mathrm{a}}$ & $9: 1$ \\
& $0-20$ & $64.6^{\mathrm{b}}$ & $5.81^{\mathrm{a}}$ & $11: 1$ \\
\hline
\end{tabular}

stand (5.19 Mg N ha'), and lowest under the black pine stand (2.37 $\left.\mathrm{Mg} \mathrm{N} \mathrm{ha}^{-1}\right)$. At the $10-20 \mathrm{~cm}$ depth, beech stand also showed the highest total nitrogen stock (4.38 Mg N ha'), and black pine stand had the lowest (1.83 $\left.\mathrm{Mg} \mathrm{N} \mathrm{ha}^{-1}\right)$. At the $0-20 \mathrm{~cm}$ total soil depth, beech stand had the highest total nitrogen stock ( $9.57 \mathrm{Mg} \mathrm{N}^{-1}$ ), followed by Scots pine stand $(5.77 \mathrm{Mg} \mathrm{N}$ ha-1) and black pine stand (4.20 Mg N ha-1 - Tab. 3 ). In general, at all soil depths considered beech stand had the lowest $\mathrm{C} / \mathrm{N}$ ratios, whereas black pine stand had the highest ratios (Tab. 3).

\section{Differences in soil $C$ and $N$ stocks} between stand age and land use type Mean soil bulk density and carbon and nitrogen concentrations of samples from the old and young fir stands and the grassland are given in Tab. 4. Soil bulk density was higher under grassland than under old and young fir stands. At the top $10 \mathrm{~cm}$, old fir stand had the greatest SOC concentration (4.54\%), followed by young fir stand (3.14\%) and grassland (2.33\%). Soil carbon concentration decreased with increasing soil depth. At the 10-20 cm depth, old fir stand had the greatest SC concentration

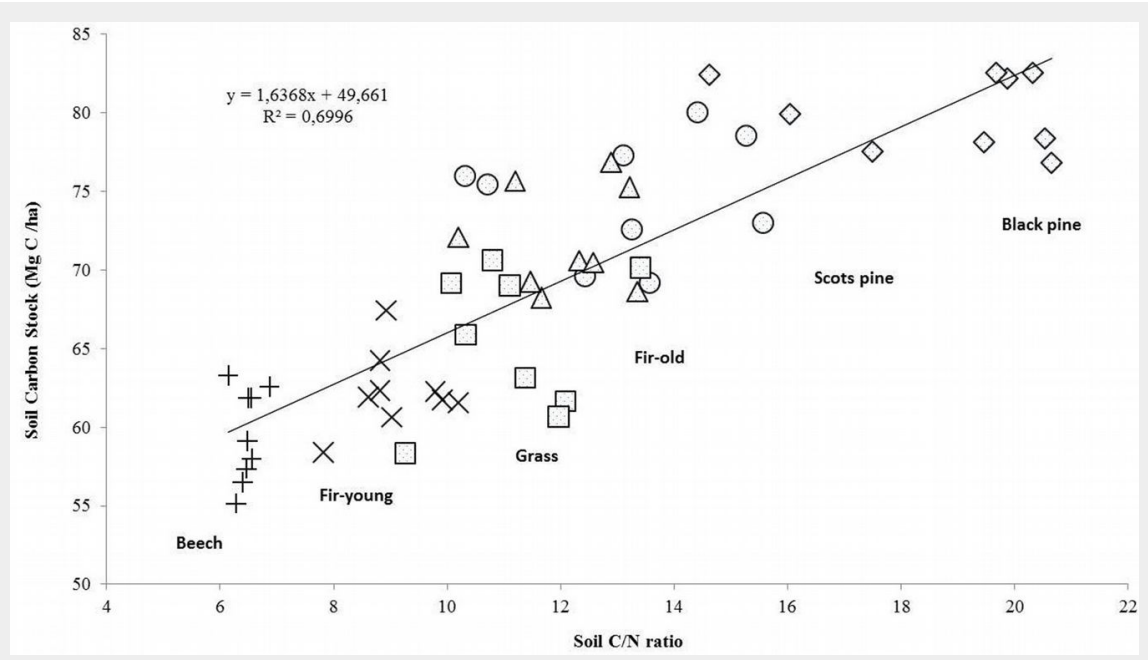

Fig. 3 - Relationship between soil $\mathrm{C} / \mathrm{N}$ concentration ratios and soil carbon stocks under Black pine $(\diamond)$, Scots pine $(\circ)$, Fir-old $(\Delta)$, Fir-young $(\times)$, beech $(+)$ and grassland () at the depth of $0-20 \mathrm{~cm}$.

(2.06\%), whereas young fir stand and grassland which showed similar percentage (1.71 and $1.79 \%$, respectively) had the lowest SC concentration. In general, when $0-20 \mathrm{~cm}$ soil depth was considered, SC concentration was highest under old fir stand $(2.80 \%)$ and lowest in the grassland soil (2.06\%). Compared to SC concentration, total nitrogen concentration at the top $10 \mathrm{~cm}$ was lowest under grassland $(0.22 \%)$ and highest under young fir stand (0.31\%). Total nitrogen concentration also decreased with increasing soil depth. At the $10-20 \mathrm{~cm}$ depth, grassland soil still had the lowest (0.13\%) and young fir stand had the highest total nitrogen concentration (0.22\%). At the $0-20$ $\mathrm{cm}$, total nitrogen concentration was the lowest under the grassland (0.17\%) and the highest under the young fir stand (0.27\%).

Regarding the soil carbon and nitrogen stocks at the $0-10 \mathrm{~cm}$ soil depth, old fir stand had the highest soil carbon stock (43.0 Mg C ha-1), followed by young fir stand (38.1 Mg C ha-1) and grassland (33.7 $\mathrm{Mg} \mathrm{C} \mathrm{ha-1} \mathrm{-} \mathrm{Tab.} \mathrm{5).} \mathrm{The} \mathrm{soil} \mathrm{carbon} \mathrm{stocks}$ also decreased with increasing soil depth. At the $10-20 \mathrm{~cm}$ depth, grassland had the greatest SC stocks (30.9 Mg C ha-1), followed by old fir stand $(27.9 \mathrm{Mg} \mathrm{C} \mathrm{ha-1)}$ and young fir stand (23.2 $\mathrm{Mg} \mathrm{C}$ ha-1). When the $0-20 \mathrm{~cm}$ total soil depth was considered, however, the old fir stand still had the highest SC stock (70.9 Mg C ha') and the young fir stand had the lowest $\left(61.3 \mathrm{Mg} C \mathrm{ha}^{-1}\right)$.

Total nitrogen stock at the top $0-10 \mathrm{~cm}$ soil depth was higher under young fir stand (3.80 Mg N ha ${ }^{-1}$ ) than under old fir stand (3.32 $\mathrm{Mg} \mathrm{N} \mathrm{ha}^{-1}$ ) and grassland (3.26 Mg N $\left.\mathrm{ha}^{-1}\right)$, the latter two showing similar values. At the $10-20 \mathrm{~cm}$ depth, young fir stand also showed a higher total nitrogen stock (3.02 $\mathrm{Mg} \mathrm{N} \mathrm{ha}{ }^{-1}$ ) than old fir stand (2.60 Mg N ha 1) and grassland $(2.55 \mathrm{Mg} \mathrm{N}$ ha-1). Considering the total soil depth analyzed (0-20 $\mathrm{cm}$ ), the old fir stand had higher total nitrogen stock $\left(6.82 \mathrm{Mg} \mathrm{N} \mathrm{ha}^{-1}\right)$ than the old fir stand (5.93 $\mathrm{Mg} \mathrm{N} \mathrm{ha}^{-1}$ ) and the grassland (5.81 Mg N ha-1 - Tab. 5). In general, grassland showed the lowest $\mathrm{C} / \mathrm{N}$ ratios at all soil depths, whereas young fir stand had the highest ratios (Tab. 5).

Soil carbon stocks from all studied sites at the depth of 0-20 cm were plotted against soil $\mathrm{C} / \mathrm{N}$ ratios (Fig. 3). A good relationship between soil $\mathrm{C} / \mathrm{N}$ ratio and mean soil carbon stocks was detected. Stands of the tree species with higher soil $\mathrm{C} / \mathrm{N}$ ratios showed a higher carbon stock in the soil. For example, beech species with lowest $\mathrm{C} / \mathrm{N}$ ratios had the lowest soil carbon stocks, whereas black pine with highest $\mathrm{C} / \mathrm{N}$ ratios had the highest soil carbon stocks (Fig. 3).

\section{Discussion}

The present study has shown that tree species, stand tree age and land-use changes can have significant effects on soil carbon and nitrogen stocks. Mineral soil in broadleaf stands (e.g., beech stands) contained less carbon than mineral soil in 
conifer stands (e.g., black pine and Scots pine), whereas conifer stands showed a lower total nitrogen stock than the broadleaf stands (Tab. 3). Moreover, significant differences among conifer tree species do exist: black pine stands had higher carbon stock than Scots pine stands. As for soil nitrogen stock, black pine stands, however, showed lower nitrogen stocks than Scots pine stands. These results confirm a general trend already reported in previous studies, i.e., soil carbon stocks under conifers are larger than under broadleaves on the same soil (Vesterdal \& Raulund-Rasmussen 1998, Augusto et al. 2002, Jandl et al. 2007). Differences in soil carbon and nitrogen stocks between tree species in this study could be attributed to differences in litter quality and quantity of tree species. Indeed, differences in the amount of litter produced and in its biochemical properties between coniferous and deciduous species affects litter decomposition rates, and eventually influence soil carbon stocks (Sariyildiz \& Anderson 2003). In general, beech litter contains more components that are difficult to decompose than black pine and Scots pine (Sariyildiz et al. 2005). Especially, beech litters with higher lignin concentrations result in litter accumulation in the forest floor and formation of acidic compounds (Sariyildiz \& Kuçuk 2008). The slower decay rates of beech litter compared to the litter of black pine and Scots pine could have contributed to the larger accumulation of carbon in forest floor under the beech stand as compared with the other coniferous stands (Sariyildiz \& Kuçuk 2008). In these acid soils, fauna are less active, decreasing the amount of humus mixing through mineral soil (Thuille \& Schulze 2006) and leaving more material in the forest floor. On the other hand, broadleaf (beech leaves and litters) contains more initial nitrogen than conifer needles and litters (Sariyildiz \& Anderson 2005). It seemed that incorporation of $\mathrm{N}$ rich litter under beech stands had likely increased soil $\mathrm{N}$ status compared to conifer tree species, which had lower soil nitrogen stocks than beech stands. The $\mathrm{C} / \mathrm{N}$ ratio of mineral soil was a good indicator of mineral carbon stock potential in soil (Fig. 3) as suggested by Akselsson et al. (2005). The strong relationships between carbon sequestration and nitrogen or $\mathrm{C} / \mathrm{N}$ ratio of mineral and forest floor organic matter have been studied by many researchers. For example, De Vries et al. (2009) showed a positive relationship between $\mathrm{N}$ deposition and $C$ sequestration in European forests, whereas Nave et al. (2009) in a metaanalysis of north temperate forest soils showed that greater $\mathrm{N}$ inputs led to a lower $\mathrm{C} / \mathrm{N}$ ratio in the forest floor, similarly to the present study (Fig. 3).

The age of trees can also affect the soil parameters investigated in this study. It is generally expected that old stand has a high soil carbon stock because soil carbon should accumulate in relatively undistur- bed forests, and some years are needed to change the soil chemistry. In this study, fir young stands ( 45 years old) showed lower carbon stocks but higher total nitrogen stocks than mature fir stands ( 82 years old) (Tab. 5). Binkley \& Valentine (1991) indicate that a change of tree species in a stand can substantially change the soil chemistry within approximately 50 years. Under 40year-old stands, Hagen-Thorn et al. (2004) did not find differences in the SOC contents between tree species, whereas Oostra et al. (2006) did find significant differences between species in stands of more than 60 years old.

Mineral soil carbon and nitrogen stocks vary with land-use change (forest to grassland). Grassland soils had lower carbon stocks compared to mature broadleaf and conifer stands, whereas it showed higher carbon stocks than young fir stands (Tab. 5). As for total nitrogen stocks, grassland soil showed different pattern as compared with tree species. The soil nitrogen stock of grasslands was higher than that of black pine stands, but lower than that of beech stands, while no significant differences with Scots pine and fir stands were detected (Tab. 5). Significant differences in the soil carbon stocks between tree stands and grassland support the general hypothesis that land-use transformation from forest to grassland or other usage (e.g., agriculture land) causes tremendous losses of terrestrial carbon that reduce the potential for land sustainability.

\section{Conclusions}

This study have demonstrated that soil carbon and nitrogen content and stock rates under similar climate conditions are significantly influenced by tree species, stand tree age and land-use change in the northwest of Turkey. Soil carbon storage is important not only because of its role in the global carbon cycle, but also because it affects forest productivity. Since soil carbon and nitrogen are principal source of energy for the nutrient-recycling activities of heterotrophic soil organisms, the maintenance of soil carbon and nitrogen stocks is vital for sustaining forest productivity. Soil carbon is one of the principal components of soil organic matter (SOM), which also contains significant amounts of water and nitrogen - all of which are exchanged between the biosphere and the atmosphere, thus affecting Earth's atmospheric chemistry, energy and water budgets, and climate. Therefore, improving our understanding of the factors that affect forest soil carbon storage is fundamental for anticipating changes in ecosystem goods and services, e.g., forest products, water resources, and greenhouse gas mitigation. A better understanding of the effect of tree species on soil carbon will enhance forest management activities, such as selection of tree species for carbon sequestration in plantation systems, design of sustainable agroforestry systems, and impro- vement of biogeochemical models.

\section{Acknowledgements}

This research has been supported by the Kastamonu University, Scientific Research Projects Coordination Department, Kastamonu, Turkey (Project Number: KUBAP-032012-07).

\section{References}

Akselsson C, Berg B, Meentemeyer V, Westling O (2005). Carbon sequestration rates in organic layers of boreal and temperate forest soils: Sweden as a case study. Global Ecology and Biogeography 14: 77-84. - doi: 10.1111/j.1466822X.2004.00133.X

Allen SE (1989). Chemical analysis of ecological materials. Blackwell Scientific Publications, Oxford, UK. pp. 368.

Augusto L, Ranger L, Binkley D, Rothe A (2002). Impact of several common tree species of European temperate forests on soil fertility. Annals of Forest Science 59: 233-253. - doi: 10.1051/ forest:2002020

Beets PN, Oliver GR, Clinton PW (2002). Soil carbon protection in podocarp/hardwood forest and effects of conversion to pasture and exotic pine forest. Environmental Pollution 116: 63-73. - doi: 10.1016/S0269-7491(01)00248-2

Binkley D, Valentine D (1991). Fifty-year biogeochemical effects of green ash, white pine, and Norway spruce in a replicated experiment. Forest Ecology and Management 40: 13-25. - doi: 10.1016/0378-1127(91)90088-D

Bouyoucos GJ (1935). The clay ratio as a criterion of susceptibility of soils to erosion. Journal of the American Society of Agronomy 27: 738-741. doi: 10.2134/agronj1935.000219620027000900 07x

Bouyoucos GJ (1962). Hydrometer method improved for making particle size analysis of soils. Agronomy Journal 54: 464-465. - doi: 10.2134/ agronj1962.00021962005400050028x

De Vries W, Reinds GJ, Gundersen P, Sterba H (2006). The impact of nitrogen deposition on carbon sequestration in European forests and forest soils. Global Change Biology 12: 1151-1173. - doi: 10.1111/j.1365-2486.2006.01151.x

De Vries W, Solberg S, Dobbertin M, Sterba H, Laubhann D, Van Oijen M, Evans C, Gundersen P, Kros J, Wamelink GWW, Reinds GJ, Sutton MA (2009). The impact of nitrogen deposition on carbon sequestration by European forests and heathlands. Forest Ecology and Management 258 (8): 1814-1823. - doi: 10.1016/j.foreco. 2009.02.034

Eviner VT, Chapin FS (2003). Functional matrix: a conceptual framework for predicting multiple plant effects on ecosystem processes. Annual Review of Ecology Evolution and Systematics 34: 455-485. - doi: 10.1146/annurev.ecolsys.34.01 1802.132342

Galloway JN, Dentener FJ, Capone DG, Boyer EW, Howarth RW, Seitzinger SP, Asner GP, Cleveland CC, Green PA, Holland EA, Karl DM, Michaels AF, Porter JH, Townsend AR, Vosmarty CJ (2004). Nitrogen cycles: past, present, and future. Biogeochemistry 70 (2): 153-226. doi: 10.1007/s10533-004-0370-0

Goodale $C L$, Apps $M J$, Birdsey RA, Field CB, Heath LS, Houghton RA, Jenkins JC, Kohlmaier 
GH, Kurz W, Liu SR, Nabuurs GJ, Nilsson S, Shvidenko $A Z$ (2002). Forest carbon sinks in the Northern Hemisphere. Ecological Applications 12: 891-899. - doi: 10.1890/1051-0761(2002)012 [0891:FCSITN]2.0.CO;2

Gülçur F (1974). Soil physical and chemical analysis methods. Istanbul University Forestry Faculty Publication no. 221, Kutulmus Press, Istanbul, Turkey, pp. 225.

Hagen-Thorn A, Callesen I, Armolaitis K, Nihlgard $B$ (2004). The impact of six European tree species on the chemistry of mineral topsoil in forest plantations on former agricultural land. Forest Ecology and Management 195: 373-384. doi: 10.1016/j.foreco.2004.02.036

Hobbie SE (2008). Nitrogen effects on decomposition: a five-year experiment in eight temperate sites. Ecology 89 (9): 2633-2644. - doi: 10.1890/07-1119.1

Houghton RA (1992). Tropical deforestation and atmospheric carbon dioxide. In: "Tropical Forests and Climate" (Myers $\mathrm{N}$ ed). Springer Science+Business Media BV, The Netherlands, pp. 99-118. - doi: 10.1007/978-94-017-3608-4_10

Houghton RA (1999). The annual net flux of carbon to the atmosphere from changes in landuse 1850-1990. Tellus 51B: 298-313. - doi: 10.103 4/j.1600-0889.1999.00013.x

Jandl R, Lindner M, Vesterdal L, Bauwens B, Baritz R, Hagedorn F, Johnson DW, Minkkinen $\mathrm{K}$, Byrne KA (2007). How strongly can forest management influence soil carbon sequestration? Geoderma 137: 253-268. - doi: 10.1016/j.geo derma.2006.09.003

Jiang C, Yu G, Fang H, Cao G, Li Y (2010). Shortterm effect of increasing nitrogen deposition on $\mathrm{CO}_{2}, \mathrm{CH}_{4}$ and $\mathrm{N}_{2} \mathrm{O}$ fluxes in an alpine meadow on the Qinghai-Tibetan Plateau, China. Atmospheric Environment 44 (24): 2920-2926. doi: 10.1016/j.atmosenv.2010.03.030

Lee J, Hopmans JW, Rolston DE, Baer SG, Six J
(2009). Determining soil carbon stock changes: simple bulk density corrections fail. Agriculture Ecosystems and Environment 134: 251-256. doi: 10.1016/j.agee.2009.07.006

Lovett GM, Weathers KC, Arthur MA (2002). Control of nitrogen loss from forested watersheds by soil carbon:nitrogen ratio and tree species composition. Ecosystems 5: 712-718. doi: 10.1007/s10021-002-0153-1

Menyailo OV, Hungate BA, Zech W (2002). The effect of single tree species on soil microbial activities related to $\mathrm{C}$ and $\mathrm{N}$ cycling in the Siberian artificial afforestation experiment. Plant and Soil 242: 183-196. - doi: 10.1023/A:101 6245619357

Mulder J, De Wit HA, Boonen HWJ, Bakken LR (2001). Increased levels of aluminum in forest soils: effects on the stores of soil organic carbon. Water, Air and Soil Pollution 130: 989-994. - doi: 10.1023/A:1013987607826

Nave LE, Vance ED, Swanston CW, Curtis PS (2009). Impacts of elevated $\mathrm{N}$ inputs on north temperate forest soil $\mathrm{C}$ storage, $\mathrm{C} / \mathrm{N}$, and net $\mathrm{N}$ mineralization. Geoderma 153 (1-2): 231-240. doi: 10.1016/j.geoderma.2009.08.012

Oostra S, Majdi H, Olsson M (2006). Impact of tree species on soil carbon stocks and soil acidity in southern Sweden. Scandinavian Journal of Forest Research 21: 364-371. - doi: 10.1080/028 27580600950172

Osher LJ, Matson PA, Amundson R (2003). Effect of land use change on soil carbon in Hawaii. Biogeochemistry 65: 213-232. - doi: 10.1023/A: 1026048612540

Sandrine L, Claude NYS, Christian W, Françoise F, Sandrine H, Paula R, Stéphane F (2006). Estimation of carbon stocks in a beech forest (Fougères Forest - W. France): extrapolation from the plots to the whole forest. Annals of Forest Science 63: 139-148. - doi: 10.1051/forest:2005 106
Sariyildiz T, Anderson JM (2003). Interactions between litter quality, decomposition and soil fertility: a laboratory study. Soil Biology and Biochemistry 35: 391-399. - doi: 10.1016/So0380717(02)00290-0

Sariyildiz T, Anderson JM (2005). Variation in the chemical composition of green leaves and leaf litters from three deciduous tree species growing on different soil types. Forest Ecology and Management 210: 303-319. - doi: 10.1016/j.for eco.2005.02.043

Sariyildiz T, Anderson JM, Kucuk M (2005). Effects of tree species and topography on soil chemistry, litter quality and decomposition in Northeast Turkey. Soil Biology and Biochemistry 37: 1695-1706. - doi: 10.1016/j.soilbio.2005. 02.004

Sariyildiz T, Kuçuk M (2008). Litter mass loss rates in deciduous and coniferous trees in Artvin, northeast Turkey: relationships with litter quality, microclimate and soil characteristics. Turkish Journal of Agriculture and Forestry 32: 547559.

Thuille A, Schulze ED (2006). Carbon dynamics in successional and afforested spruce stands in Thuringia and the Alps. Global Change Biology 12: 325-342. - doi: 10.1111/j.1365-2486.2005.010 78. $\mathrm{x}$

Vesterdal L, Raulund-Rasmussen K (1998). Forest floor chemistry under seven tree species along a soil fertility gradient. Canadian Journal of Forest Research 28: 1636-1647. - doi: 10.1139/x98140

Vesterdal L, Schmidt IK, Callesen I, Nilsson LO, Gundersen P (2008). Carbon and nitrogen in forest floor and mineral soil under six common European tree species. Forest Ecology and Management 255: 35-48. - doi: 10.1016/j.foreco. 2007.08.015 